\title{
Presbiakuzi: Patofizyoloji, Değerlendirme ve Güncel Yaklaşımlar
}

\author{
Betül ÖZDEMIR*
}

\begin{abstract}
$\ddot{O} \mathbf{z}$
Dünya nüfusu içinde yaşlı nüfusu giderek artmaktadır ve yaşa bağlı işitme kaybı daha yaygın hale gelmektedir. Yaşlanmaya bağlı olarak zamanla gelişen işitme kaybı presbiakuzi olarak tanımlanmaktadır. Presbiakuzinin yeterince teşhis edilmediği ve yeterince rehabilite edilmediği bilinmektedir. Bu derlemenin amacı, yaşlılarda yaygın olarak görünen presbiakuzinin prevelansı, patofizyolojisi, değerlendirme yöntemleri, tedavi ve rehabilitasyonu hakkında literatürde yer alan önemli kaynaklardan bilgileri sunmaktır. Presbiakuzide en çok tercih edilen rehabilitasyon şekli işitme cihazlarıdır. Erken teşhis ve erken cihazlandırmanın önemi konusunda farkındalık oluşturmak amaçlanmıştır. Ayrıca hastalı̆̆ın patofizyolojisini anlamak; yaklaşımlar geliştirmek, işitme cihazları, yardımcı dinleme sistemleri ve işitsel terapi için sağlanan kaynakları genişletmek için büyük önem taşıyacaktır. İşitme bozukluğu olan kişiler için etkili cihazlarının kullanımı ve eğitim stratejileri, yaşlıların yaşam kalitesi üzerinde olumlu etkiyi ortaya çıkartmaktadır.
\end{abstract}

Anahtar Sözcükler: Yaşlı, presbiakuzi, işitme, cihaz, koklear implantlar.

Presbycusis: Pathophysiology, Evaluation and Current Approaches

\begin{abstract}
The elderly population is increasing in the world population, and age-related hearing loss is becoming more common. Hearing loss that develops over time due to aging is defined as presbycusis. It is known that presbycusis is underdiagnosed and not adequately rehabilitated. The aim of this review is to present information from important sources in the literature about the prevalence, pathophysiology, evaluation methods, treatment and rehabilitation of presbycusis, which is common in the elderly. The most preferred form of rehabilitation for presbycusis is hearing aids. It is aimed to raise awareness about the importance of early diagnosis and early instrumentation. Also, understanding the pathophysiology of the disease will be crucial for developing approaches and expanding the resources available for hearing aids, assistive listening systems and auditory therapy. The use of effective devices and educational strategies for people with hearing impairment can have a positive impact on the quality of life of the elderly.
\end{abstract}

Keywords: Elderly, presbycusis, hearing, device, cochlear implants.

\section{Giriş}

\section{Kısa Tarihçe}

Presbiakuzi terimi, New Yorklu otolog St. John Roosa tarafından ilk kez kullanılmıştır. Adını Yunanca "yaşlı adam" ve "duymak" kelimelerinden almaktadır ${ }^{1}$.Yaşlanmanın etkilerini, yaşlılıkta işitme bozulmasına neden olan diğer faktörlerden ayırt etmek zor olduğundan, presbiakuzi terimi yaşlılık işitme kaybı ile eş anlamlı olarak kullanılmaktadır².

Derleme Makale (Review Article)

Geliş / Received: 13.07.2021 \& Kabul / Accepted: 08.12.2021

DOI: https://doi.org/10.38079/igusabder.971019

${ }^{*}$ Arş. Gör., İstanbul Sağllk ve Teknoloji Üniversitesi, Sağllk Bilimleri Fakültesi, Odyoloji Bölümü, İstanbul, Türkiye,

E-posta: betulozdemiiir@gmail.com ORCID https://orcid.org/oooo-0002-2184-9818 


\section{Tanım}

1899'da Zwaardemaker, ileri yaş ile yüksek frekanslı işitme kaybı arasındaki bağlantıyı tanımlamıştır. Pearlman presbiakuziyi, saf ses odyogramında beklenenden daha kötü konuşma ayırt etme skoru olan (fonemik gerileme), rekruitmentı olmayan, gürültüye maruziyet öyküsü bulunmayan, bilateral simetrik sensörinöral işitme kaybı olan bir sendrom olarak tanımlamıştır3. Tanı odyometri ile doğrulanabilmektedir4. Presbiakuzinin ayırt edici özelliği, konuşmanın yüksek frekanslı bileşenlerini (/p/, /k/, /f/, /s/ ve /ş/ gibi sessiz ünsüzler) anlama yeteneğinin bozulmasıdir².

Yaşa bağlı işitme kaybı genellikle yaşamın beşinci on yılından sonra başlar. Bununla birlikte, yaşa bağlı işitme kaybının 8 kHz'in üzerindeki frekanslar hesaba katıldığında çok daha erken başladığına inanılmaktadır. İkinci on yılda insanların \%16'sı üçüncü on yılda \%50'si ve dördüncü on yılda neredeyse tüm insanlar saf ses odyogramında herhangi bir işitme kaybı saptanmadan, 8 kHz'in üzerindeki frekanslarda işitme eşiğinde bir azalma göstermektedir5.

\section{Epidemiyoloji}

Araştırmacılar tarafından presbiakuzinin insidansı ve prevelansı ile ilgili çeşitli raporlar yayınlanmıştır. İşitme kaybını tanımlamak için kullanılan kriterler araştırmacılar arasında farklılık gösterdiğinden dolayı kesin yaygınlığı belirlemek zordur.

Presbiakuzi, yaşam boyu işitme kaybından kaynaklanan en büyük toplumsal ve ekonomik yükü oluşturmaktadır ve mevcut demografik değişimlerle artması beklenmektedir6. Yapılan araştırmalarda dünya çapında yaşla birlikte yaygınlıkta benzer artışlar bulunmuştur. Presbiakuzi, 75 yaşına kadar yaşlı yetişkinlerin yarısından fazlasını ve 90 yaşın üzerindeki hemen hemen tüm yetişkinleri etkilemektedir7.

Ülkemizde, T.C. Aile, Çalışma ve Sosyal Hizmetler Bakanlığı Engelli ve Yaşlı Hizmetleri Genel Müdürlüğünün 2011'de yayınladığı rapora göre işitmede zorluk yaşayan engellilerin oranı \%1,1 (yaklaşık 850 bin) olarak belirlenmiştir ${ }^{8}$. Dünya Sağlık Örgütü tarafından 2050 yılına kadar 60 yaşın üzerinde 500 milyon kadar yaşa bağlı işitme kaybı olacağı tahmin edilmektedir9.

Şekil 1. Uluslararası Standardizasyon Örgütü (ISO) 7029 standardına göre yaşa bağlı işitme kaybı.

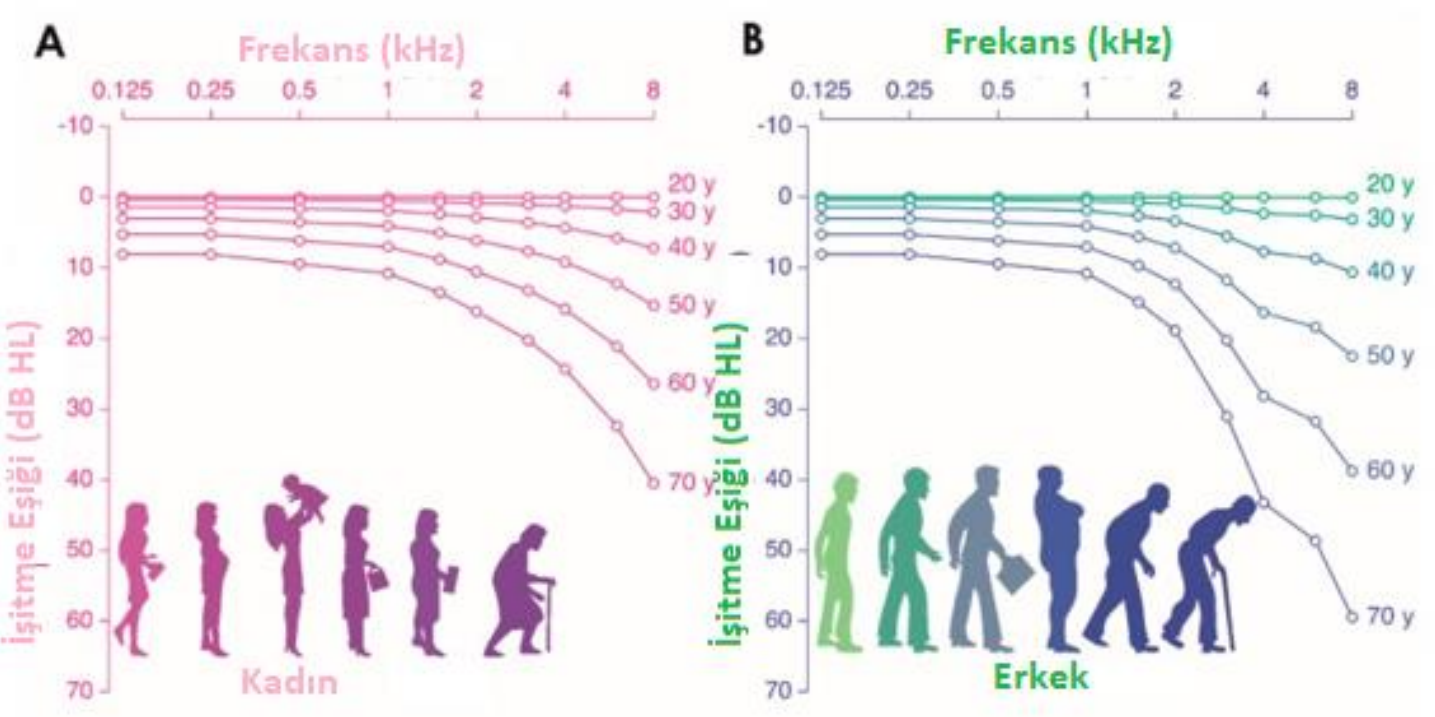


Kadınlar (A) ve erkekler (B) için odyogramlar gösterilmiştir. X ekseni frekansı (Hz) ve y ekseni ses şiddetini (dB HL) göstermektedir. Her bir grafik, belirli bir yaştaki medyan odyogramı temsil etmektedir (20 ila 70 yaş arası, 10 yıllık artışlarla) ${ }^{10}$.

\section{Patofizyoloji}

Yaşlanmayla ilişkili oluşan işitme kayıpları karakteristik olarak sensörinöral tip işitme kaybı oluşturur, iletim tipi bir kayıp oluşturmamaktadır. Buna göre, bu tür işitme kayıplarının patolojik bağlantıları iç kulak yapıları ile ilgilidir. Yaşlanan orta kulakta ciddi işitme kaybına neden olabilecek belgelenmiş bir değişiklik olmadığından, bu rapor presbiakuziye bağlı iç kulak patolojisi ile ilgilenecektir.

Presbiakuzinin çok faktörlü olduğu düşünülmektedir ve bazı bileşenleri tam olarak anlaşılamamıştır. Genetik gibi hem içsel faktörler hem de dış faktörler (gürültüye maruz kalma, sigara kullanımı, ilaçlar vb.) söz konusu olmaktadır.

Presbiakuzinin ilk belirtisi olan işitme spektrumunda yüksek frekans bölgesindeki eşik duyarlılığının kaybı zamanla daha alçak frekans alanlarına doğru ilerler. Ayrıca insanda kokleanın bazalinde dış tüy hücrelerinde kayıp vardır. Duyusal presbiakuzi olarak adlandırılan bu tür tüy hücresi kaybının, odyometrik modeli, genellikle $4 \mathrm{kHz}$ bölgesinde bir çentik veya düşüşle, dik eğimli yüksek frekans kaybıdır. Yaşa bağlı hastalıklar diğer faktörler yüke katkıda bulunabilir. İşitme kaybı, bu çeşitli faktörlerin etkilerinden kaynaklanır, ancak her zaman doğrusal bir şekilde değildir. Örneğin, işitmedeki yaş değişiklikleri zamanla hızlanırken gürültüden kaynaklanan işitme kaybı zamanla yavaşlama eğilimindedir².

Çevresel gürültünün presbiakuziye katkıda bulunduğu, Goycoolea ve meslektaşları tarafından desteklenmiştir. Tüm hayatlarını Paskalya Adası'nın sessizliğinde yaşayan insanların yaşla birlikte hafif derecede işitme kaybı, 3-5 yıl gibi kısa süreler boyunca daha gürültülü olan ana karada yaşayan akrabalarından daha az bulunmuştur ${ }^{11}$.

İnsanlar ve memeli türleri arasında kulağın yapısı ve işlevindeki dikkate değer benzerlikler nedeniyle, hastalığın nedeni ve doğasının iç kulak üzerindeki etkilerinin anlaşılmasında hayvan çalışmaları hayati önem taşımaktadır.

\section{Stria Vaskülaris / Spiral Bağ}

Yaşlı koklealarda spiral bağın durumu, stria vaskülaris ve damar yapısı daha az değerlendirilse de bu yapıların dejenerasyonu yaşlı insan temporal kemiklerinde gözlenmiş ve ölçülmüştür ve önemli bir patolojiyi temsil etmektedir ${ }^{12-14}$.

Sessiz ortamda yaşlanmış gerbil, sıçan ve av köpeği koklealarında, aynı lokasyonlarda vasküler dejenerasyona bağlı koklear kanalın her iki ucunda strial ve spiral ligament dejenerasyonu $\operatorname{vardir}^{15-17}$.

Sinir ucundan üretilen hücrelerin gelişimi ve korunmasında rol oynayan bir transkripsiyon faktörü olan Sox10, yaşlı CBA / CaJ fare koklealarında ve aynı zamanda insan temporal kemiklerinde stria vaskülaris ve spiral bağ hücrelerinde azalır ${ }^{18}$. Azaltılmış ATPaz ekspresyonu dahil olmak üzere bu patolojinin sonucu, endokoklear potansiyelde bir azalmaya sebep olur ${ }^{19}$. Bu potansiyel, stria vaskülaris hücreleri tarafından üretilir, iletim akımı ve koklear amplifikatör için enerji kaynağı olarak hizmet eder ${ }^{20}$. İletim akımının ve endokoklear potansiyelin kaybı, azalan amplifikasyon nedeniyle yüksek frekanslı işitme üzerinde en büyük etkiye sahiptir. Gürültüye maruz kalmayan yaşlı insanlarda çok yaygın olan, saf ses odyogramlarında görülen $1-2 \mathrm{kHz}$ 'in üzerindeki işitme eşiklerinde artışı açıklamaktadır ${ }^{21}$. 
Dubno ve arkadaşları ${ }^{22}$, gürültüye maruz kaldığı bilinen yaşlı insanların saf ses odyogramlarını sınıflandırmak için patolojinin doğru bir şekilde belirlenebildiği hayvan çalışmalarından alınan odyogramları kullandı. Endokoklear potansiyelin kaybının, insanlarda odyometrik eşik kaymalarının ana nedeni ve dolayısıyla yaşa bağlı işitme kaybının altında yatan ana koklear faktör olduğu sonucuna varılmıştır.

\section{Duyusal Tüy Hücreleri}

Bredberg, yenidoğanlardan, 90 yaşın üzerindeki 78 kişiden 125 kokleadan bu hücrelerin ayrıntılı bir analizini rapor etmiş̧ir. Dış tüy hücrelerinin yaşla birlikte dejenerasyona daha duyarlı olduğunu göstermenin yanı sıra hem apikal hem de bazal koklear dönüsslerde dejenere olduklarını belgelemiştir. Yaşlı insanlarda ortak odyometrik bulgu yüksek frekanslı işitme kaybı olduğu için, sonraki araştırmalar koklear bazal dönüşe odaklanmıştır. Bu nedenle genel algı, kokleanın bazal dönüşünde duyu hücrelerinin kaybının yaşa bağlı işitme kaybının başlıca koklear patolojisi olduğu bildirilmiştir ${ }^{23}$.

Dış tüylü hücrelerin ve bazal dönüşteki elektro-hareketliliğinin kaybı, yüksek frekanslı sesler için amplifikasyon kaybına neden olmaktadır24. Böylece endokoklear potansiyel kaybı ile gözlenene benzer bir işitme kaybı yaratır19. Koklea apikal bölgede dış tüy hücrelerinin kaybı, alçak frekanslı işitme eşikleri üzerinde büyük bir etkiye sahip değildir çünkü elektro-hareketlilik amplifikasyonu (20 dB), yüksek frekanslı sesler için olduğu kadar büyük değildir. Bu hücrelerin dağınık kaybının baziler membran mekaniğine etkisi bilinmemektedir. İç tüy hücrelerinin kaybı, bu tüy hücreleri tarafından kodlanan spesifik frekansta bir duyu kaybına neden olmaktadır ${ }^{25}$.

\section{3. İşitsel Nöronlar / Spiral Ganglion Hücreleri}

Nöral dejenerasyon hem insanlarda hem de diğer hayvanlarda yaşlı iç kulağın çok yaygın bir patolojisidir ve hem apikal hem de bazal koklear dönüşlerde meydana gelmektedir ${ }^{26}$.

Nöron kaybı, işitsel beyin sapı cevap (ABR) eşiklerinin yükselmesine neden olmaz, insanlarda odyometrik eşikleri etkilemez ve bu nedenle yaşa bağlı işitme kaybı fikirlerinde en aza indirilmiştir. Nöron kaybına bağlı olarak merkezi sinir sistemine yetersiz uyaran kodlama bilgisi, özellikle yaşlı dinleyicilerin ortak bir sorunu olan konuşma gibi seslerin ayırt edilmesinde zorluklara yol açması muhtemel görülmektedir ${ }^{27}$.

\section{Genetik}

Yapılan birçok çalışmada araştırmacılar, işitme kaybına katkıda bulunan çok sayıda ve değişken genetik faktörlerin ve çevresel faktörlerin yaşlılıkta işitme kaybına eşit katkıda bulunduğu sonucuna varmışlardır ${ }^{28}$. Çevrenin büyük bir rol oynaması, işitme kaybının yaşlanmanın kaçınılmaz bir parçası olmadığı anlamına gelmektedir. İnsan genetiği ile ilgili gelecekteki çalışmalar, gürültüye maruz kaldığı bilinen insanları dışlamaya çalışmalıdır. İşitme kaybının başlangıç yaşı ile genetik profillerine göre düşüş oranı arasında ilişki kurmak için zaman içinde insanları takip etmek de değerli olacaktır.

Daha yakın tarihli bir raporda, Vuckovic ve arkadaşları, yaşa bağlı işitme kaybı ile ilgili 21 potansiyel gen ve buna karşı koruma sağlayabilecek 2 gen, CSMD1 ve PTRPD belirlemişlerdir29.

İç kulağın sağlıklı işleyişine katkıda bulunan birçok gen vardır ve genetik analitik teknikler geliştikçe, hangi genlerin gözlenen patolojiye izin verdiğinin daha net bir resmi ortaya çıacağ düşünülmektedir. O zamana kadar, hayvan koklearında şu anda tanımlanmış birçok farklı gen ürününün lokalize edilmesi, işitmeyi nasıl etkileyebileceklerini belirlemeye yardımcı olacaktır. 


\section{Metabolizma / Mitokondriyal Aktivite}

İç kulak, stria vaskülaris tarafından üretilen endokoklear potansiyeli korumak, dış tüy hücrelerinde hareketliliğe yardımcı olmak, sinaptik aktivite yapmak ve spiral gangliondaki işitsel nöronların spontan ve sese dayalı deşarjlarını korumak için enerji kullanmaktadır. Stria vaskülaris hücreleri, tüy hücreleri ve nöronların hepsi yüksek konsantrasyonlarda mitokondri ve $\mathrm{Na} / \mathrm{K}-\mathrm{ATPaz}$ içeriri17, 30-33.

Mitokondride hücresel solunum yoluyla sağlanan enerji, hücrenin hayatta kalması için gereklidir ve oksidatif fosforilasyon yoluyla yeterli enerji sağlama yeteneğinin azalması, kesinlikle tüm dokularda, özellikle enerji gerektiren kokleada potansiyel bir hücre kaybı mekanizmasıdır34,35.

Yaşa bağlı hücresel dejenerasyona katkıda bulunan mitokondriyal disfonksiyona işaret eden birçok deney olsa da bu organellerin yaşlı hücrelerdeki işlevini doğrudan test etmek için daha iyi analizlere ihtiyaç duyulduğu görülmektedir.

\section{Gürültüye Maruz Kalma}

Uzun süreli çalışmalar, gençliklerinde koklear hasar gördüğü düşünülen kişilerde presbiakuzinin diğerlerine göre daha şiddetli olduğunu göstermiştir 36 . Geçici veya hemen işitme kaybına neden olmayan gürültüye maruz kalmanın neden olduğu koklear hasarının aslında presbiakuziyi hızlandırabileceğine inanılmaktadır. Ne yazık ki, gürültüye maruz kalmanın insanlarda presbiakuzi üzerindeki uzun vadeli etkisini tam olarak anlamak mümkün değildir çünkü pek çok faktör kontrol edilemez. Ancak hayvan modellerinde, yalnızca geçici eşik artışlarına neden olan gürültüye maruz kalma, kalıcı spiral ganglion nöronlarının kaybına neden olabilir ve presbiakuziyi hızlandırabilir $27,37,38$.

İnsan kokleasının bazal ucundaki tüy hücrelerinin, özellikle de dış tüy hücrelerinin büyük kaybı, yüksek olasılıkla sağlıklı yaşlanmanın değil, akustik travmanın sonucudur39. Apekste tüy hücresi ölüm mekanizması bilinmemektedir.

Uzun yıllar süren gürültüye maruz kalma deneyleri, koklear hücre dejenerasyonuna yol açan gürültü seviyelerini ve süresini detaylandırmıştır. Mills ve meslektaşları ${ }^{40}$, sessiz ortamda büyütülen gerbiller, gürültülü ortamda büyütülen hayvan gruplarından daha fazla presbiakuzi tanısı aldığını gösterdi. Kaybın değişkenliği, sessiz ortamda büyütülmüş grupta, gürültülü ortamda büyütülen gruba göre çok daha fazlaydı. Gürültünün ve yaşlanmanın etkilerinin etkileşimi tam olarak anlaşlamamıştır çünkü kısmen gürültü ve yaşlanmanın her ikisi de önce kokleanın yüksek frekanslı bölgelerini etkilemektedir. Bununla birlikte gürültü hasarı 3-6 kHz frekans aralığında eşik yükselmesi ile tanımlanırken, yaşa bağlı en erken etkileri ise en yüksek test frekanslarında (genellikle $8 \mathrm{kHz}$ ) görülmektedir.

\section{Ototoksik İlaçlar}

Salisilatlar, loop diüretikler, aminoglikozid ve bazı kemoterapötik ajanlar dahil olmak üzere ototoksisite ile ilişkili çoklu ilaçlar vardır41-43. Ek olarak, Toluen, stiren, kurşun, karbonmonoksit, cıva ve diğer toksinler gibi kimyasallara iş ve çevre ile ilgili bazı maruziyetlerin ototoksisiteye neden olduğu gösterilmiştir44. Bu ajanlara maruz kalmayı en aza indirmek yaşa bağlı işitme kaybını önlemeye yardımcı olabilir45.

Ototoksik ilaçlara, özellikle kemoterapötik ajanlara ve aminoglikozid antibiyotiklere maruz kalmak koklear dejenerasyona ve işitme kaybına yol açmaktadır ancak mekanizmaları göz önüne alındığında yaşa bağlı işitme kaybından ayrı olarak düşünülmelidir46,47. 


\section{Enflamasyon}

Enflamasyonu azaltmak ve böylece iç kulağı korumak için çok sayıda farmasötik madde mevcut olduğundan, yaşam boyu iç kulak enflamatuar aktivitesi üzerine daha fazla araştırma klinik olarak ilgili bilgiler üretmelidir 48 .

\section{Hormonal Faktörler}

Hayvanlarda ve insanlarda androjen ve alfa ve beta östrojen reseptörleri tespit edilmiştir. İlginç bir şekilde, bu reseptörlerin ekspresyonunun yetişkin kokleanın duyu epitelinde düzenlendiği bulunmuştur, bu da onların fizyolojik bir rol oynamaları gerektiğini düşündürmektedir49.

Glukokortikoidler, cinsiyet hormonları ve glutamat sinyallerinin presbiakuzide rol oynadığı düşünülmektedir ${ }^{\circ}$. Uzamış kortikosteron seviyeleri ve nükleer faktör kappa B kaybı, artan spiral ganglion nöron kaybı ile ilişkilendirilmiştir51,52.

Yumurtalıkları alınmış farelerde E2 reseptörü ile kronik tedavi, merkezi (inferior kollikulus) ve periferik (koklea) işitsel yollarda moleküler değişiklikler ürettiği gözlemlenmiştir53.

\section{Değerlendirme}

Presbiakuzi hastalarının değerlendirilme basamakları temel olarak beş aşamadan meydana gelmektedir ve bunlar:

1. Hasta ve yakınından hikâye alınması, bildirilen semptomların ayrıntılı şekilde belirlenmesi presbiakuzinin doğru tanılanması açısından önem arz etmektedir. Çoğu durumda, aile ve arkadaşlar sorunun hastadan daha fazla farkındadır.

2. Fiziksel muayene, yaşlı insanlarda sık görülen bir problem olan kulak kirinin çıkarılmasından sonra genellikle normaldir. Muayenede yarı saydam kulak zarının opaklaşması yaygın olarak görülür ve normaldir. Bunun ses enerjisinin iletimi üzerinde etkisi yoktur ve sadece yaşın bir tezahürüdür².

3. İşitme kaybı taraması, 60 yaşın üzerindeki kişilerde presbiakuzi prevalansının yüksek olması sebebiyle yıllık olarak fiziksel muayenelerde yapılmalıdır. İşitme kaybının sosyal ve ekonomik yaşam üzerindeki olumsuz etkileri göz önüne alındığında bu tarama çok uygun maliyetli bir araçtır.

4. Saf ses işitme testi, presbiakuziyi teşhis etmek ve değerlendirmek için önemli bir araçtır. Yaşlılar test talimatlarını takip etmekte zorluk çekebilir ve test zaman alıcı olduğu için bitkin hissedebilirler. Bu nedenle testten önce hastaya test anlatılmalı ve talimatlar verilmelidir54.

5. Konuşma odyometrisi testi, presbiakuzi hastaları, diğer insanların ne söylediğini dinleme ve anlamada zorluk çekebilir. Presbiakuzili hastalarda konuşmayı duyma ve anlama yeteneğini ölçmek, uygun tedavi yöntemlerini seçmek ve sonuçları yorumlamak için çok önemlidir. Saf ses işitme testi ile karşılaştırıldığında, konuşma odyometri testi daha karmaşık ve kapsamlıdır çünkü konuşmanın fizyolojik, dilsel ve psikolojik yönlerini inceler, böylece presbiakuzi hastalarında çok önemlidir55.

Diğer birçok test mevcuttur. Presbiakuzili hastalarda, periferik işitme organları ve beyin arasında koordinasyon eksikliği olduğu için sesleri duyma ve konuşmayı işleme yeteneği bozulur. Saf ses işitme testi gibi geleneksel işitme testleri işitme yeteneğini doğru bir şekilde ölçmez ve daha da önemlisi, bu testler presbiakuzili hastaların günlük yaşamlarında karşılaştıkları zorluk derecesini ölçmez ${ }^{5}$. Doğru bir işitme testi için, gürültüdeki konuşmayı tanıma yeteneğinin ölçülmesi gerekir. Daha yaygın olarak kullanılabilen, gürültüde konuşmayı anlama (HINT) testidir57. 
Merkezi işitsel işlevi değerlendirmek için dikkatle hazırlanmış konuşma materyalleri kullanmaktadır.

\section{Tedavi ve Yönetim}

Kaybedilen işitmeyi geri kazandıracak tedaviler hâlen mevcut değildir. İşitme restorasyonu araştırmaları büyüyen bir bilimsel alandır. İşitme kaybı için potansiyel gen ve hormon tedavileri hakkında devam eden araştırmalar vardır. Bireysel genetik yatkınlık ve deneklerin fizyolojik durumu, terapötik müdahalelerin başarısını etkileyebilecek kafa karıştırıcı faktörlerdir. Tabii ki gürültüden ve ototoksik ilaçlar, diyabet, yüksek tansiyon ve kalp hastalıkları gibi diğer risk faktörlerinden kaçınmak, koklear tüy hücrelerinin zarar görmesini önlemeye yardımcı olabilir ve bu da yaşamın sonraki dönemlerinde presbiakuzinin etkilerini en aza indirebilir ${ }^{10}$.

Diğer bir zorluk, koklear terapilerde ilaçların etkinliğini artırmak için nano taşıyıcılar gibi ilaçların hedefe yönelik dağıtımına duyulan ihtiyaçtır. Kimyasallar, proteinler veya gen ürünleri dahil olmak üzere çok çeşitli moleküllerin kapsüllenmesine izin veren gözenekli bir matrise sahip çok işlevli nanopartiküllerin geliştirilmesi, gelecekteki koklear tedavileri için umut verici bir bakış açısıdır58.

Son olarak, uzun süreli ilaç tüketiminden kaynaklanan potansiyel risklerle ilgilidir. Antioksidanların veya vitaminlerin kısa süreli uygulanması güvenli olsa da klinik çalışmaların meta analizleri, beta-karoten, A vitamini ve diğer vitaminlerin uzun süreli uygulanmasının genel mortalite artışı ile ilişkili olduğunu göstermektedir59.

Yaşa bağlı işitme kaybının tedavisinde faydalı olabilecek diğer tedaviler arasında kök hücre ve gen tedavileri yer almaktadır ${ }^{60}$. Presbiakuzi tedavisi sadece çok nadiren cerrahiyi içerir. Örneğin, orta kulak hastalıkları ve orta kulağında kronik iltihap olan hastalarda bir seçenektir61.

\section{Rehabilitasyon}

İşitsel rehabilitasyon için sağllk kuruluşu ve odyoloğu içeren işbirlikçi, disiplinlerarası bir yaklaşım önerilmektedir62.

İşitme cihazları ve koklear implantasyon yoluyla işitme kaybının rehabilitasyonu, yaşam kalitesine kısa ve uzun vadeli faydalar sağlayarak ruh halini ve sosyal etkileşimi iyileştirir, kişiye özel rehabilitasyon programlarının sunulması büyük önem taşımaktadır.

İşitme kaybından kaynaklanan dezavantajları en aza indirgemek bu uygulamaların en önemli amacıdır. Mevcut işitme cihazları gelişen teknoloji ile hem çeşitlendi hem de donanım özellikleri ile birden fazla ortama göre ayarlanabilen ve ortamda sesleri birbirinden ayırt edip işitme sistemine veren, rüzgâr sesini baskılayabilen türleri mevcuttur. Yaşlı bireylerde her türlü cihaz uygulamasında kişinin sosyal ve iş yaşamı, çevresinin yardımı, ince-kalın motor becerileri ile maddi olanakları ve kozmetik kaygıları da göz önünde tutulması gereken en önemli faktörlerdir. Rehabilitasyonda en önemlisi presbiakuzili kişinin işitme kaybının tipi ve derecesine göre işitme cihaz seçiminde model ve özelliklerinin seçilmesi gerekliliğidir. Odyolog, tüm bunları göz önünde bulundurarak kişiye presbiakuzi yönetimi için en uygun özellikteki cihazı seçmelidir. Çevre sesleri en aza indiren yardımcı dinleme cihazlarıyla bireylerin yaşam kalitesi de artırılmaya çalışılmalıdır.63,64 Amplifikasyon, iletişimi kolaylaştırmaya yardımcı olmak için dinleme becerilerinin öğretimi ile birleştirilmelidir. İşitme cihazlarının dikkate alınmasına ek olarak, iletişim stratejilerinin öğretilmesi önemlidir. Arka plandaki gürültüyü en aza indirmek, yüz yüze etkileşimi teşvik etmek ve hastalara iyi anlamayı sağlamak için duyduklarını yeniden ifade etmeyi ve özetlemeyi öğretmek, iletişimi geliş̧irmeye yardımcı olan stratejilerdir65. 
Bir çalışmada Han ve arkadaşları ${ }^{66}$ işitsel rehabilitasyonun depresyon gelişimine karşı önleyici bir etkisi olabileceğini göstermektedir.

Rehabilitasyonda bir diğer önemli konu, cihaz ile rehabilitasyonun yanı sıra iletişimin nezaket kuralları içerisinde olması gerektiğidir. Konuşmacı: dinleyici ile yüz yüze olmalı, anlaşılır ve acele etmeden konuşmalı ve mesajın alındığından emin olmalıdır. İşitme kayıplı dinleyici de iletişim konusunda ciddi olmalı ve yanlış anlaşılmaların düzeltilebilmesi için duyduklarını tekrarlamak için adımlar atmalıdır. Bu ilkeler tüm işitme kayıpları dereceleri için geçerlidir.

Gürültüde veya yankı yapan salonlarda bozulmuş konuşma sinyallerini anlamak daha zordur. Bu tür problemlerin, merkezi işitsel sistemin konuşma seslerini anlamlı dil öğelerine entegre etme ve sentezleme yeteneğinin yavaşladığını gösterdiği düşünülmektedir. Bu nedenle, dinleme ortamını genellikle basit yollarla (radyoyu kapatmak, daha yavaş konuşmak) optimize etmenin, konuşmayı anlama üzerinde önemli etkileri vardır.

\section{Yaşlılık Döneminde İşitme Kaybının Psikososyal Etkileri}

Araştırmalar, işitme kaybı olan kişilerin normal sosyal aktivitelerinde azalma, aile veya arkadaşlarla ilişkilerinde artan sorunlar, iş yerinde duygusal zorluklar ve ayrıca daha yüksek düzeyde kaygı, depresyon, kişilerarası duyarlılık ve düşmanlık olduğunu göstermektedir 67,68.

İşitme kaybı olan 50 yaşın üzerindeki kişiler içinden rehabilite edilmeyenlerin depresyon, kaygı, öfke, hayal kırıklığı, duygusal dengesizlik ve paranoya bildirme olasılıkları daha yüksek bulunmuştur ve rehabilite edilenlere göre toplu sosyal aktivitelere katılma olasılıkları daha düşük olduğu bulunmuştur ${ }^{69,70}$.

Bernabei ve arkadaşları¹, 61 ila 75 yaş arasındaki bireylerde işitme kaybı ile depresyon arasında anlamlı bir ilişki olduğunu bulmuşlardır. Aynı çalışmada, işitme kaybı olan bireylerin, normal işiten katılımcılara kıyasla kaygı geliştirme olasılıkları daha yüksek olduğu belirtilmiştir. Sonuçlar, yaşla birlikte işitme kaybının depresif belirtiler ve kaygı geliştirme olasılı̆̆ını artırabileceğini düşündürmektedir.

\section{Sonuç ve Öneriler}

Yaşlanan kokleada hücre kaybına neden olan mekanizmalar incelenmiştir. Hastanın öyküsü alınıp uygun değerlendirme yöntemleri seçildikten sonra yaşlı bireylerin sosyal çevreden izole olmalarını ve bilişsel gerileme yaşamalarını azaltmak için odyolog ve diğer bilim dalları iş birliği içerisinde en uygun tedavi seçeneği belirlenip rehabilitasyona başlamalıdır. Yaşa bağlı işitme kaybı insanların yaşam kalitelerini büyük ölçüde etkiler, kişileri duyusal girdilerden yoksun bırakır. Günümüzde yaşadığımız pandemi koşulları da göz önünde bulundurulduğunda insanların yalnız başlarına kaldıkları zamanlarda modern rehabilitasyon yöntemleri düşük yaşam kalitesinin, yalnızlığın, bağımlılığın ve memnuniyetsizliğin giderilmesine katkıda bulunacaktır.

Devam eden araştırmalar ile bu hastalık ve patofizyolojisi hakkında, presbiakuzinin ilerlemesine çare bulmak için farkındalığımız güçlendirilmelidir. En önemli nokta, işitme problemini etkili bir şekilde yönetmek için işitme kaybının beraberinde getirdiği tüm sorunlar odyologlar ve diğer temel bilim uzmanları ile bir arada değerlendirilmelidir. İşitme kaybına yaklaşım içerisinde bireyin yakın çevresine de büyük bir sorumluluk düşmektedir. Konu ile ilk karşllan olarak aile hekimleri, yaşlı bireylerdeki işitme kaybına yaklaşımda ihtiyacı olanları kulak burun boğaz ve odyoloji iş birliğinde olan kliniklerine yönlendirerek kişinin yaşam kalitesinin artırılmasında ve sosyal hayata katılmasında önemli rol oynamalıdırlar. 


\section{KAYNAKLAR}

1. Roosa D. Presbykousis. Trans Am Otol Soc. 1885;449-460.

2. Gates GA, Mills JH. Presbycusis. Lancet. 2005;366(9491):1111-1120. doi:10.1016/So1406736(05)67423-5.

3. Pearlman RC. Presbycusis: the need for a clinical definition. The American journal of otology. 1982;3:183-186.

4. Zahnert T. The differential diagnosis of hearing loss. Dtsch Arztebl Int. 2011;108(25):433444. doi:10.3238/arztebl.2011.0433.

5. Arvin B, Prepageran N, Raman R. "High frequency presbycusis"-is there an earlier onset? Indian J Otolaryngol Head Neck Surg. 2013;65(Suppl 3):480-484. doi:10.1007/s12070-011-0356-x.

6. World Health Organization. Age-related factors. World Health Organization. https://www.who.int/teams/noncommunicable-diseases/sensory-functions-disabilityand-rehabilitation/highlighting-priorities-for-ear-and-hearing-care. Yayınlanma tarihi Mart 2021. Erişim tarihi 03 Ağustos 2021.

7. Wattamwar K, Qian ZJ, Otter J, et al. Increases in the rate of age-related hearing loss in the older old. JAMA Otolaryngol Head Neck Surg. 2017;143(1):41-45. doi:10.1001/jamaoto.2016.2661.

8. T.C. Aile, Çalışma ve Sosyal Hizmetler Bakanlığı. Engelli Nufüs. https://www.ailevecalisma.gov.tr/media/42250/istatistik-bulteni-2020-mart.pdf. Yayınlanma tarihi Mart 2020. Erişim tarihi 12 Haziran 2021.

9. Ma A, Jufas N, Patel N. Hearing loss in the elderly. Australian Doctor News. https://www.ausdoc.com.au/. Yayınlanma tarihi Mayıs 2020. Erişim tarihi o3 Ağustos 2021.

10. Wang J, Puel J-L. Presbycusis: an update on cochlear mechanisms and therapies. Journal of Clinical Medicine. 2020;9(1):218. https://doi.org/10.3390/jcm9010218.

11. Goycoolea MV, Goycoolea HG, Farfan CR, Rodriguez LG, Martinez GC, Vidal R. Effect of life in industrialized societies on hearing in natives of Easter Island. Laryngoscope. 1986;96(12):1391-1396. doi:10.1288/o0005537-198612000-00015.

12. Kurata N, Schachern PA, Paparella MM, Cureoglu S. Histopathologic evaluation of vascular findings in the cochlea in patients with presbycusis. JAMA Otolaryngol Head Neck Surg. 2016;142(2):173-178. doi:10.1001/jamaoto.2015.3163.

13. Schuknecht HF, Gacek MR. Cochlear pathology in presbycusis. Ann Otol Rhinol Laryngol. 1993;102(1 Pt 2):1-16. doi:10.1177/00034894931020S101.

14. Suzuki T, Nomoto Y, Nakagawa T, et al. Age-dependent degeneration of the stria vascularis in human cochleae. Laryngoscope. 2006;116(10):1846-1850. doi:10.1097/o1.mlg.0000234940.33569.39.

15. Gratton MA, Smyth BJ, Lam CF, Boettcher FA, Schmiedt RA. Decline in the endocochlear potential corresponds to decreased Na,K-ATPase activity in the lateral wall of quiet-aged gerbils. Hear Res. 1997;108(1-2):9-16. doi:10.1016/s0378-5955(97)00034-8.

16. Le T, Keithley EM. Effects of antioxidants on the aging inner ear. Hear Res. 2007;226(12):194-202. doi:10.1016/j.heares.2006.04.003.

17. Spicer SS, Schulte BA. Spiral ligament pathology in quiet-aged gerbils. Hear Res. 2002;172(1-2):172-185. doi:10.1016/s0378-5955(02)00581-6.

18. Hao X, Xing Y, Moore MW, et al. Sox1o expressing cells in the lateral wall of the aged mouse and human cochlea. PLoS One. 2014;9(6):e97389. doi:10.1371/journal.pone.0097389.

19. Gordon-Salant S, Frisina RD, Popper AN, Fay RR. The aging auditory system. 1st ed. New 
York, NY: Springer; 2010:9-38.

20. Wangemann P. Supporting sensory transduction: cochlear fluid homeostasis and the endocochlear potential. $J$ Physiol. 2006;576(Pt 1):11-21. doi:10.1113/jphysiol.2006.112888.

21. Lang H, Jyothi V, Smythe NM, Dubno JR, Schulte BA, Schmiedt RA. Chronic reduction of endocochlear potential reduces auditory nerve activity: further confirmation of an animal model of metabolic presbyacusis. $J$ Assoc Res Otolaryngol. 2010;11(3):419-434. doi:10.1007/s10162-010-0214-7.

22. Dubno JR, Eckert MA, Lee FS, Matthews LJ, Schmiedt RA. Classifying human audiometric phenotypes of age-related hearing loss from animal models. $J$ Assoc Res Otolaryngol. 2013 ;14(5):687-701. doi: 10.1007/s10162-013-0396-x.

23. Bredberg G. Cellular pattern and nerve supply of the human organ of corti: a preliminary report. Arch Otolaryngol. 1965;82(5):462-469. doi:10.1001/archotol.1965.00760010464003.

24. Liberman MC, Kiang NY. Acoustic trauma in cats: Cochlear pathology and auditory-nerve activity. Acta Otolaryngol Suppl. 1978;358:1-63.

25. Wu PZ, Liberman LD, Bennett K, et al. Primary neural degeneration in the human cochlea: Evidence for hidden hearing loss in the aging ear. Neuroscience. 2019;407:8-20. doi:10.1016/j.neuroscience.2018.07.053.

26. Makary CA, Shin J, Kujawa SG, Liberman MC, Merchant SN. Age-related primary cochlear neuronal degeneration in human temporal bones. $J$ Assoc Res Otolaryngol. 2011;12(6):711717. doi:10.1007/s10162-011-0283-2.

27. Kujawa SG, Liberman MC. Adding insult to injury: cochlear nerve degeneration after "temporary" noise-induced hearing loss. J Neurosci. 2009;29(45):14077-14085. doi:10.1523/JNEUROSCI.2845-09.2009.

28. Fransen E, Bonneux S, Corneveaux JJ, et al. Genome-wide association analysis demonstrates the highly polygenic character of age-related hearing impairment. Eur J Hum Genet. 2015;23(1):110-115. doi:10.1038/ejhg.2014.56.

29. Vuckovic D, Mezzavilla M, Cocca M, et al. Whole-genome sequencing reveals new insights into age-related hearing loss: cumulative effects, pleiotropy and the role of selection. Eur $J$ Hum Genet. 2018;26(8):1167-1179. doi:10.1038/s41431-018-0126-2.

30. Nakazawa K, Spicer SS, Schulte BA. Ultrastructural localization of Na,K-ATPase in the gerbil cochlea. $J$ Histochem Cytochem. 1995;43(10):981-991. doi:10.1177/43.10.7560888.

31. Ding B, Walton JP, Zhu X, Frisina RD. Age-related changes in Na, K-ATPase expression, subunit isoform selection and assembly in the stria vascularis lateral wall of mouse cochlea. Hear Res. 2018;367:59-73. doi:10.1016/j.heares.2018.07.006.

32. Ryan AF, Watts AG. Expression of mRNAs encoding alpha and beta subunit isoforms of the Na,K-ATPase in the rat cochlea. Mol Cell Neurosci. 1991;2(2):179-187. doi:10.1016/10447431(91)90011-c.

33. Schulte BA, Adams JC. Distribution of immunoreactive $\mathrm{Na}+\mathrm{K}+-\mathrm{ATPase}$ in gerbil cochlea. $J$ Histochem Cytochem. 1989;37(2):127-134. doi:10.1177/37.2.2536055.

34. Madreiter-Sokolowski CT, Sokolowski AA, Waldeck-Weiermair M, Malli R, Graier WF. Targeting mitochondria to counteract age-related cellular dysfunction. Genes. 2018; 9(3):165. doi.org/10.3390/genes9030165.

35. Pickles JO. Mutation in mitochondrial DNA as a cause of presbyacusis. Audiol Neurootol. 2004;9(1):23-33. doi:10.1159/000074184.

36. Gates GA, Schmid P, Kujawa SG, Nam B, D'Agostino R. Longitudinal threshold changes in older men with audiometric notches. Hear Res. 2000;141(1-2):220-228.

doi:10.1016/so378-5955(99)oo223-3. 
37. Kujawa SG, Liberman MC. Acceleration of age-related hearing loss by early noise exposure: Evidence of a misspent youth. $J$ Neurosci. 2006;26(7):2115-2123. doi:10.1523/JNEUROSCI.4985-05.2006.

38. Lin HW, Furman AC, Kujawa SG, Liberman MC. Primary neural degeneration in the guinea pig cochlea after reversible noise-induced threshold shift. J Assoc Res Otolaryngol. 2011;12(5):605-616. doi:10.1007/s10162-011-0277-0.

39. Johnsson LG, Hawkins JE Jr. Degeneration patterns in human ears exposed to noise. Ann Otol Rhinol Laryngol. 1976;85(6 PT. 1):725-739. doi:10.1177/000348947608500603.

40. Mills JH, Schmiedt RA, Kulish LF. Age-related changes in auditory potentials of mongolian gerbil. Hear Res. 1990;46(3):201-210. doi:10.1016/0378-5955(90)90002-7.

41. Brien JA. Ototoxicity associated with salicylates: A brief review. Drug Saf. 1993;9(2):143148. doi:10.2165/00002018-199309020-00006.

42. Hoffman DW, Whitworth CA, Jones KL, Rybak LP. Nutritional status, glutathione levels, and ototoxicity of loop diuretics and aminoglycoside antibiotics. Hear Res. 1987;31(3):217222. doi:10.1016/0378-5955(87)90190-0.

43. Rybak LP, Whitworth C, Somani S. Application of antioxidants and other agents to prevent cisplatin ototoxicity. Laryngoscope. 1999;109(11):1740-1744. doi:10.1097/00005537199911000-00003.

44. Nies E. Ototoxic substances at the workplace: a brief update. Arh Hig Rada Toksikol. 2012;63(2):147-152. doi:10.2478/10004-1254-63-2012-2199.

45. Bielefeld EC, Tanaka C, Chen GD, Henderson D. Age-related hearing loss: is it a preventable condition?. Hear Res. 2010;264(1-2):98-107. doi:10.1016/j.heares.2009.09.001.

46. Jiang M, Karasawa T, Steyger PS. Aminoglycoside-induced cochleotoxicity: a review. Front Cell Neurosci. 2017;11:308. doi:10.3389/fncel.2017.00308.

47. Steyger PS, Cunningham LL, Esquivel CR, Watts KL, Zuo J. Editorial: cellular mechanisms of ototoxicity. Front Cell Neurosci. 2018;12:75. doi:10.3389/fncel.2018.00075.

48. Watson N, Ding B, Zhu X, Frisina RD. Chronic inflammation - inflammaging - in the ageing cochlea: A novel target for future presbycusis therapy. Ageing Res Rev. 2017;40:142-148. doi:10.1016/j.arr.2017.10.002.

49. Guerra J, Devesa J. Hormone therapy: Challenges for treating hearing impairments. $S N$ Compr Clin Med. 2019:603-615. https://doi.org/10.1007/s42399-019-00089-y.

50. Kidd Iii AR, Bao J. Recent advances in the study of age-related hearing loss: a mini-review. Gerontology. 2012;58(6):490-496. doi:10.1159/000338588.

51. Shen H, Lin Z, Lei D, Han J, Ohlemiller KK, Bao J. Old mice lacking high-affinity nicotine receptors resist acoustic trauma. Hear Res. 2011;277(1-2):184-191. doi:10.1016/j.heares.2011.01.009.

52. Lang H, Schulte BA, Zhou D, Smythe N, Spicer SS, Schmiedt RA. Nuclear factor kappaB deficiency is associated with auditory nerve degeneration and increased noise-induced hearing loss. J Neurosci. 2006;26(13):3541-3550. doi:10.1523/JNEUROSCI.2488-05.2006.

53. Charitidi K, Meltser I, Canlon B. Estradiol treatment and hormonal fluctuations during the estrous cycle modulate the expression of estrogen receptors in the auditory system and the prepulse inhibition of acoustic startle response. Endocrinology. 2012;153(9):4412-4421. doi:10.1210/en.2012-1416.

54. Kim TS, Chung JW. Evaluation of age-related hearing loss. Korean J Audiol. 2013;17(2):50-53. doi:10.7874/kja.2013.17.2.50.

55. Schubert K. A new audiometer and results obtained with its use. Z Laryngol Rhinol Otol. 1951;30(1):11-26. doi: 10.7162/S1809-97772013000300005. 
56. American Academy of Otolaryngology and the American Council of Otolaryngology. Guide for the evaluation of hearing handicap. JAMA. 1979;241(19):2055-2059. doi:10.1001/jama.1979.03290450053025.

57. Çekiç S. Gürültüde Konuşmayı Anlama Testi [yüksek lisans tezi]. Ankara, Türkiye: Hacettepe Üniversitesi Sağllk Bilimleri Enstitüsü; 2006.

58. Pyykkö I, Zou J, Schrott-Fischer A, Glueckert R, Kinnunen P. An overview of nanoparticle based delivery for treatment of inner ear disorders. Methods Mol Biol. 2016;1427:363-415. doi:10.1007/978-1-4939-3615-1_21.

59. Miller RA. Evaluating evidence for aging. Science. 2005;310(5747):441-443. doi:10.1126/science.310.5747.441.

6o. Ren H, Chen J, Wang Y, Zhang S, Zhang B. Intracerebral neural stem cell transplantation improved the auditory of mice with presbycusis. Int J Clin Exp Pathol. 2013;6(2):230.

61. Löhler J, Cebulla M, Shehata Dieler W, Volkenstein S, Völter C, Walther LE. Hearing impairment in old age. Dtsch Arztebl Int. 2019;116(17):301-310. doi:10.3238/arztebl.2019.0301.

62. Ko J. Presbycusis and its management. Br J Nurs. 2010;19(3):160-165. doi:10.12968/bjon.2010.19.3.46536.

63. Nilsson P, Vesterager V, Sibelle P, Sieck L, Christensen B. A double-blind cross-over study of a non-linear hearing aid. Audiology. 1997;36(6):325-338.

doi:10.3109/00206099709071983.

64. Yueh B, Souza PE, McDowell JA, et al. Randomized trial of amplification strategies. Arch Otolaryngol Head Neck Surg. 2001;127(10):1197-1204. doi:10.1001/archotol.127.10.1197.

65. Contrera KJ, Wallhagen MI, Mamo SK, Oh ES, Lin FR. Hearing Loss Health Care for Older Adults. J Am Board Fam Med. 2016;29(3):394-403. doi:10.3122/jabfm.2016.03.150235.

66. Han JH, Lee HJ, Jung J, Park EC. Effects of self-reported hearing or vision impairment on depressive symptoms: a population-based longitudinal study. Epidemiol Psychiatr Sci. 2019;28(3):343-355. doi:10.1017/S2045796018000045.

67. Baraldi Gdos S, de Almeida LC, Borges AC. Hearing loss in aging. Braz J Otorhinolaryngol. 2007;73(1):58-64. doi:10.1016/s1808-8694(15)31123-x.

68. Most T, Aviner C. Auditory, visual, and auditory-visual perception of emotions by individuals with cochlear implants, hearing AIDS, and normal hearing. J Deaf Stud Deaf Educ. 2009;14(4):449-464. doi:10.1093/deafed/enpoo7.

69. Better Hearing Institute. Hearing Healthcare Professionals. Obtido de Better Hearing, Institute. Better Hearing. https://betterhearing.org/hearingpedia/hearing-careprofessionals/. Yayınlanma tarihi 2015. Erişim tarihi 11 Ağustos 2021.

70. Linssen AM, Joore MA, Theunissen EJ, Anteunis LJ. The effects and costs of a hearing screening and rehabilitation program in residential care homes for the elderly in the Netherlands. Am J Audiol. 2013;22(1):186-189. doi:10.1044/1059-0889(2013/12-0058).

71. Bernabei V, Morini V, Moretti F, et al. Vision and hearing impairments are associated with depressive anxiety syndrome in Italian elderly. Aging Ment Health. 2011;15(4):467-474. doi:10.1080/13607863.2011.562483. 